\title{
https://doi.org/10.46344/JBINO.2020.v09i04.11
}

\section{A COMPARATIVE EXPLORATORY TRIAL ON GROWTH OF SPIRULINA PLATENSIS WITH SERIALLY DYNAMISED HOMOEOPATHIC PREPARATIONS FOR QUALITATIVE AND QUANTITATIVE AUGMENTATION.}

\author{
Sivaramyapragathi R.S ${ }^{*}$, Chandraja C.V ${ }^{2}$ and Ajith kumar M.V3 \\ IInternee, Sarada Krishna Homoeopathic Medical College, Kulasekhram. TN, India. \\ 2 Department of Medical Research, Sarada Krishna Homoeopathic Medical College, Kulasekhram. TN, \\ India. \\ ${ }^{3}$ Department of Community Medicine, Sarada Krishna Homoeopathic Medical College, Kulasekhram , TN, \\ India. \\ (Received on Date: 30 $0^{\text {th }}$ March 2020 Date of Acceptance: 13 th May 2020 Date of Publish: $01^{\text {st }}$ July 2020 ) \\ Email id: chandrajarathish@gmail.com
}

\begin{abstract}
Spirulina platensis is a symbiotic, single celled, filamentous blue green alga. In-vitro growth of spirulina needs Magnesium, MgSo4, Phosphorus, Selenium and $\mathrm{NaCl}$. This study was conducted by exclude these nutrients individually in the crude form and instead administer the chemicals in the homoeopathic dilutions forms. The notable results were high bio mass, protein, chlorophyll and yield than the standard Media. The antibacterial activity was sensitive against Bacillus subtilis and Proteus vulgaris. This new field paved a way for the upcoming researchers to grow cheaper, contaminants free, fast growing, high quality and healthier spirulina.
\end{abstract}

KEYWORDS : spirulina plantensis, cyanobacteria, RM6 media, photosynthesis, yield 


\section{INTRODUCTION}

Spirulina platensis is a symbiotic, single celled, filamentous blue green algae; rich in micro and macro nutrients. Normal in vitro growth of spirulina can be enhance with the help of certain chemicals such as Magnesium, Magnesium sulphate, Phosphorus, Selenium, Single Super Phosphate, Sodium Nitrate, Potassium
Chloride, Calcium Chloride, Sodium Bicarbonate and sodium chloride.These are the constituents of RM6 media. This study was conducted to know the action of homoeopathic ultra-dilutions upon the Spirulina growth. Due to the high cost and heavy metal contaminations, Spirulina was not consumed by many peoples. Spirulina is the best source of proteins , that we can reduce the cost.

\section{METHODOLOGY}

\begin{tabular}{|c|c|c|}
\hline GONTENTS & AMOUN & CORRESPONDING MEDICINES \\
\hline $\begin{array}{l}\text { Single Super } \\
\text { Phosphate (SSP) }\end{array}$ & $1.25 \mathrm{~g}$ & PHOSPHORUS \\
\hline $\begin{array}{l}\text { Sodium Nitrate } \\
\text { (NaNO3) }\end{array}$ & $2.5 \mathrm{~g}$ & NATRIUM NITRICUM \\
\hline $\begin{array}{l}\text { Potassium Chloride } \\
\text { (KCI) }\end{array}$ & $0.5 \mathrm{~g}$ & KALIUM MURIATICUM \\
\hline $\begin{array}{l}\text { Sodium Chloride } \\
\text { (NaCI) }\end{array}$ & $0.5 \mathrm{~g}$ & NATRIUM MURIATICUM \\
\hline $\begin{array}{l}\text { Magnesium Sulfate } \\
\text { (MgSO4) }\end{array}$ & $0.75 \mathrm{~g}$ & $\begin{array}{l}\text { MAGNESIUM SULPHURICUM } 8 \\
\text { MAGNESIUM ACETICUM }\end{array}$ \\
\hline $\begin{array}{l}\text { Calcium Chloride } \\
\text { (CaCl2) }\end{array}$ & $0.04 \mathrm{~g}$ & CALCAREA MURIATICUM \\
\hline $\begin{array}{l}\text { Sodium Bicarbonate } \\
\text { (NaHCO3) }\end{array}$ & $8 g$ & - \\
\hline
\end{tabular}

Twenty two Erlenmeyer flasks ( of $500 \mathrm{ml}$ capacity ) were sterilized and $250 \mathrm{ml}$ of sterilized RM6 Media was poured to all conical flasks under sterile environment and plugged up with cotton.The inoculation room was set up with air conditioning facility $\left(28-32^{\circ} \mathrm{C}\right)$. The part of the room was illuminated with a tube light to aids the photosynthesis .On 27 / 03/ 2019, one $\mathrm{ml}$ of mother Spirulina was inoculated in all flasks. In set 1 , the MgSO4 removed from the RM6 Media, instead of that we add MAGNESIUM SULPHURICUM 6C,12C,30C in set 1 and
Mgso4 free RM6 Media was considered as a control in both set 1 and 2 , in set 2 also $\mathrm{MgSO} 4$ was removed but MAGNESIUM ACETICUM 6C,12C,30C was added separately. In set $3, \mathrm{NaCl}$ was removed from the $\mathrm{RM} 6$ media, here $\mathrm{NaCl}$ free RM 6 Media was considered as control, we give NATRUM MURIATICUM 6C, 12C, 30C separately.In set 4 and 5 , the whole RM6 media was taken but in addition to that we added PHOSPHORUS 6C,12C,30, and SELENIUM METALLICUM 6C,12C,30C .In these set 4 \& 5 , RM6Media proper was taken as a ino.com | Innovative Association 
control .In set 6 , the distilled water was converted into Alkaline water by the addition of $\mathrm{NaHCO} 3$ and $\mathrm{NaOH}$ and added MAG.SULP, PHOS, SELEN.MET, NAT.MUR,CALC.MUR， KALI.MUR， NAT.NIT combined form of 6C,12C,30C potencies. For every 3 days $\mathrm{pH}$, bio mass and OD was verified. After 45 days the samples were filtered and analysed.

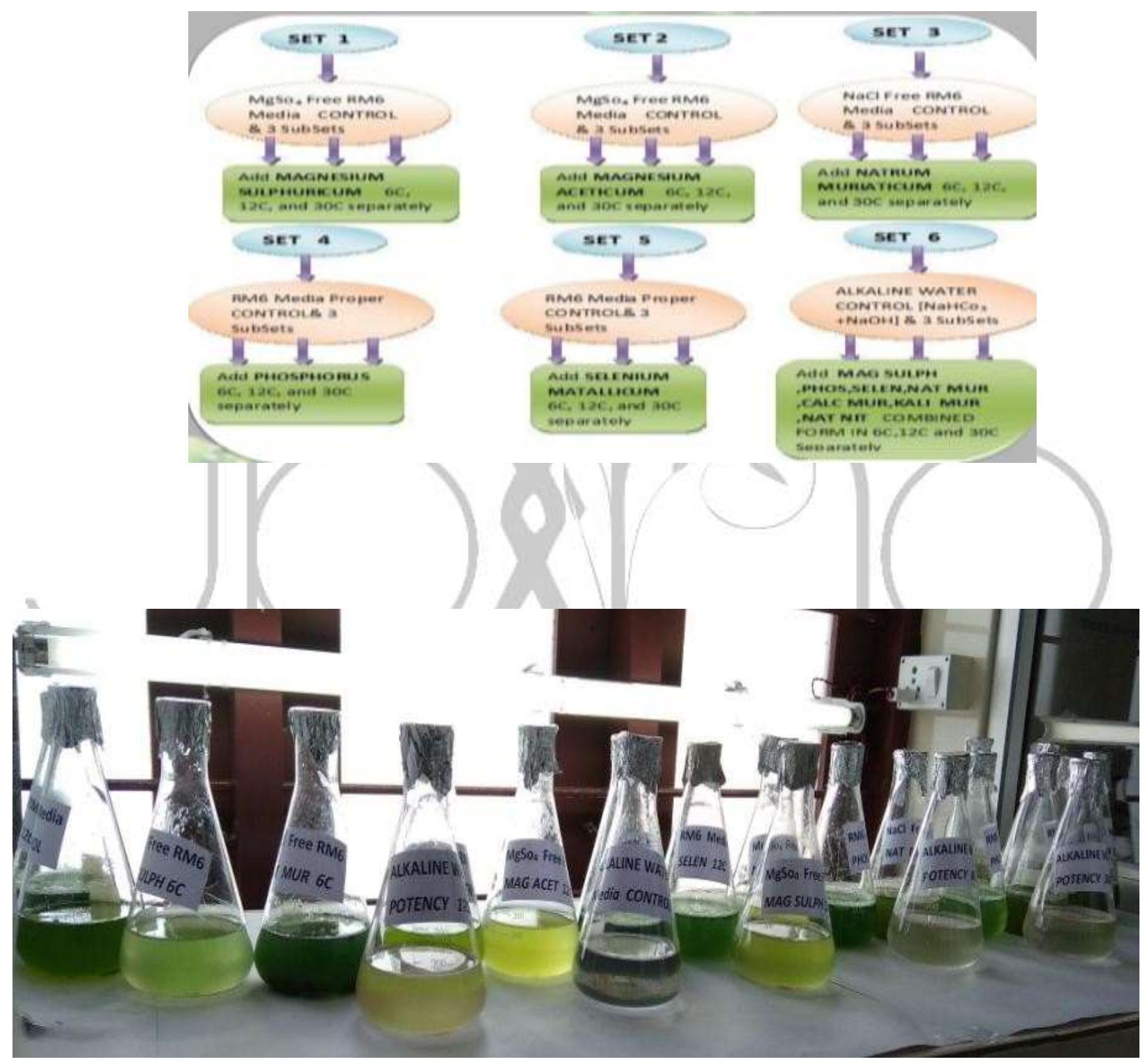




\section{RESULTS}

\section{GRAPH: 1}

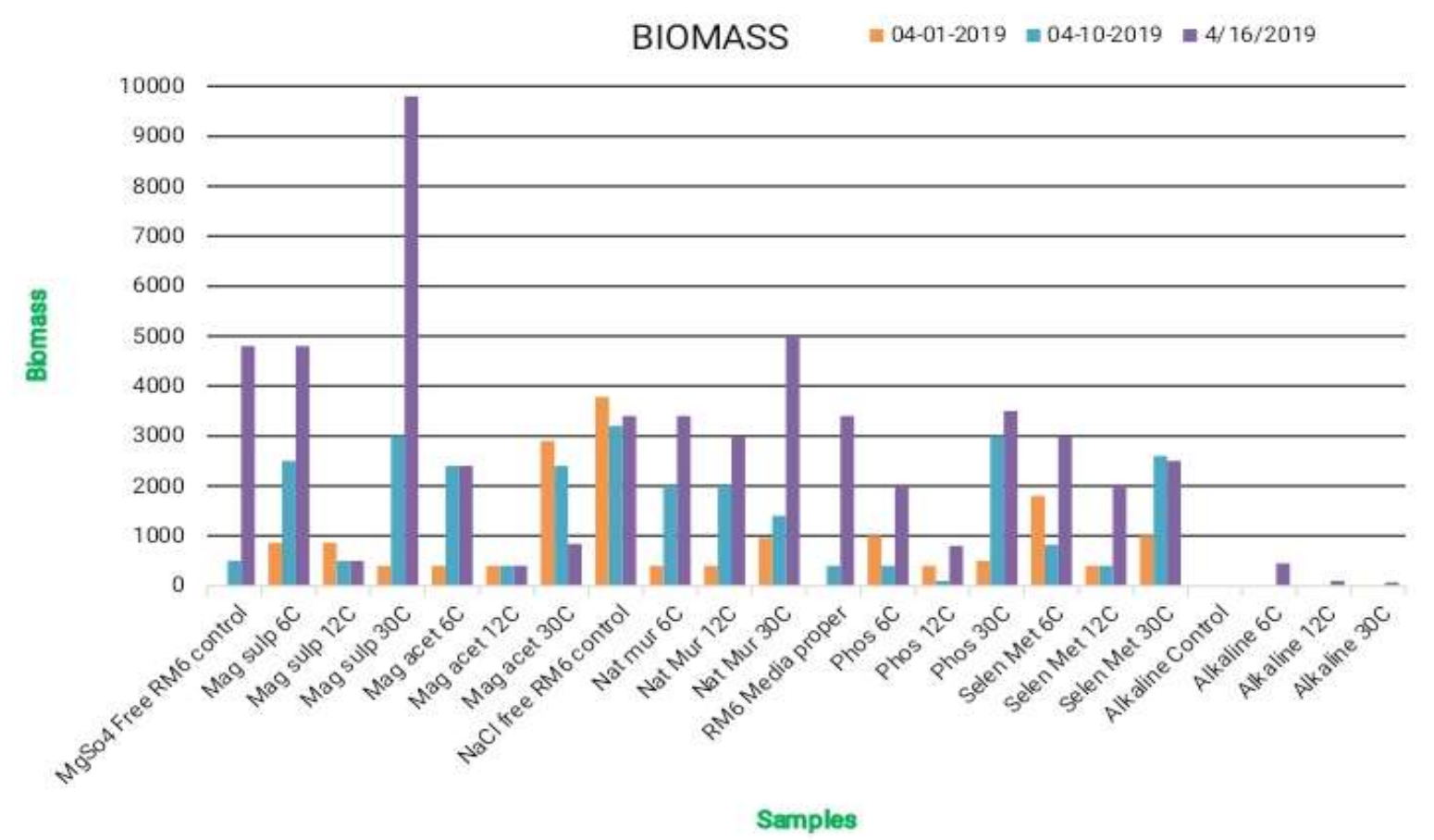

This graph explain the correlation between the biomass values of all the 22 samples, Thus, it discloses which culture has shown better growth. It was found that the cultured grown using Mag Sulph 30C showed the maximum growth and Alkaline control showed no growth at all.

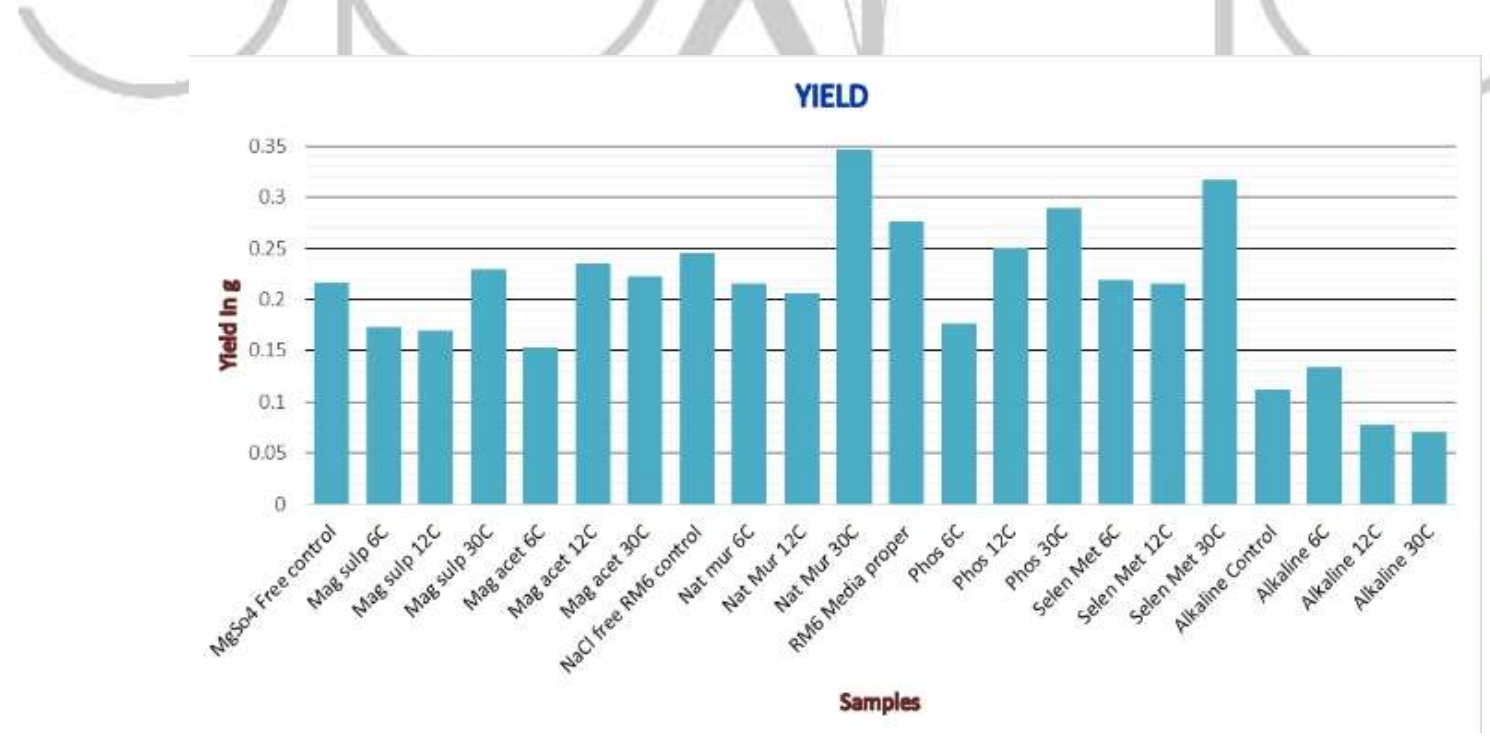




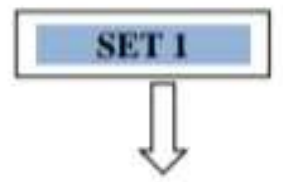

3 Sub sets

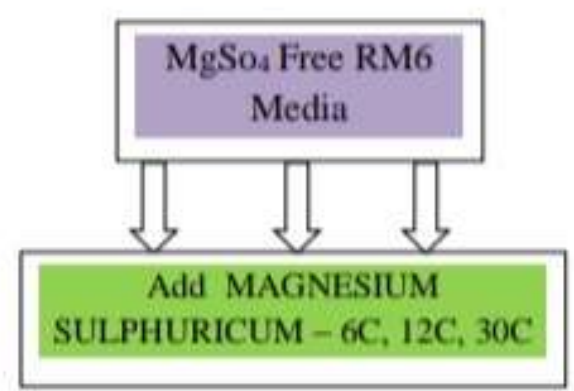

\section{SET 4}

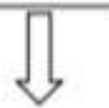

3 Sub set

\section{RM6 Media Proper}

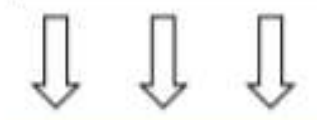

PHOSPHORUS -

$6 \mathrm{C}, 12 \mathrm{C} 30 \mathrm{C}$

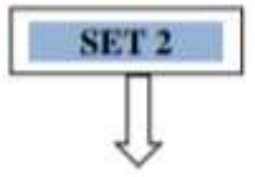

3 Sub sets
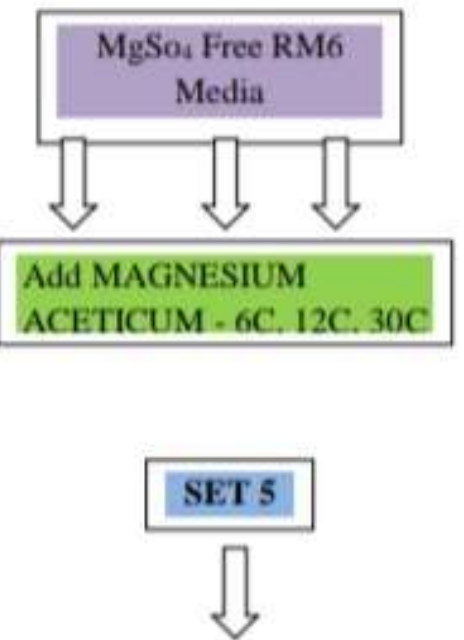

3 Sub set

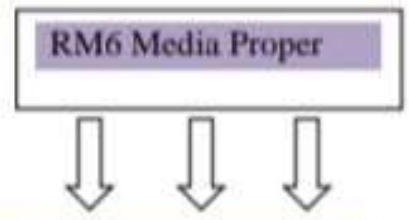

SELENIUM .MET $6 \mathrm{C}, 12 \mathrm{C}, 30 \mathrm{C}$

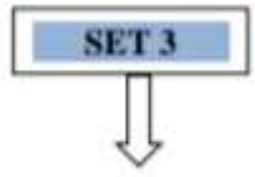

3 Sub sets
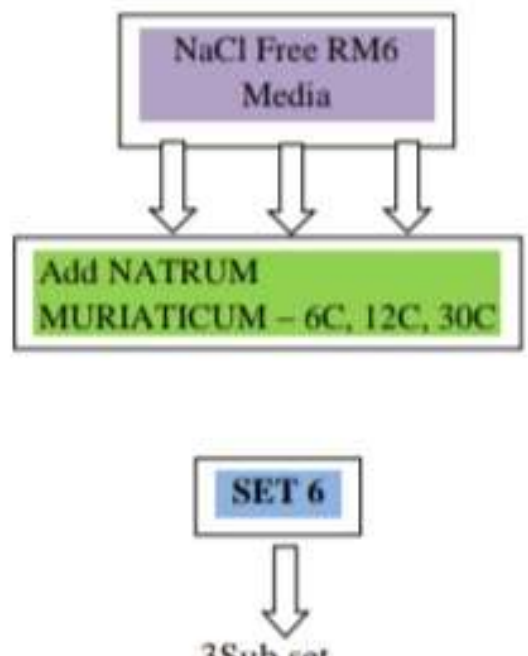

3 Sub set

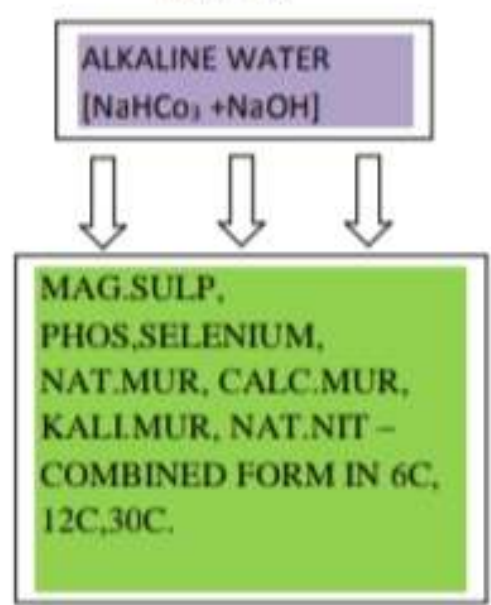


This graph explain the correlation between the final weight of all the 22 samples. It has been found out that the cultured grown using Nat Mur $30 \mathrm{C}$ showed the maximum yield and that grown with Alkaline $30 \mathrm{C}$ showed minimum yield.

GRAPH : 3

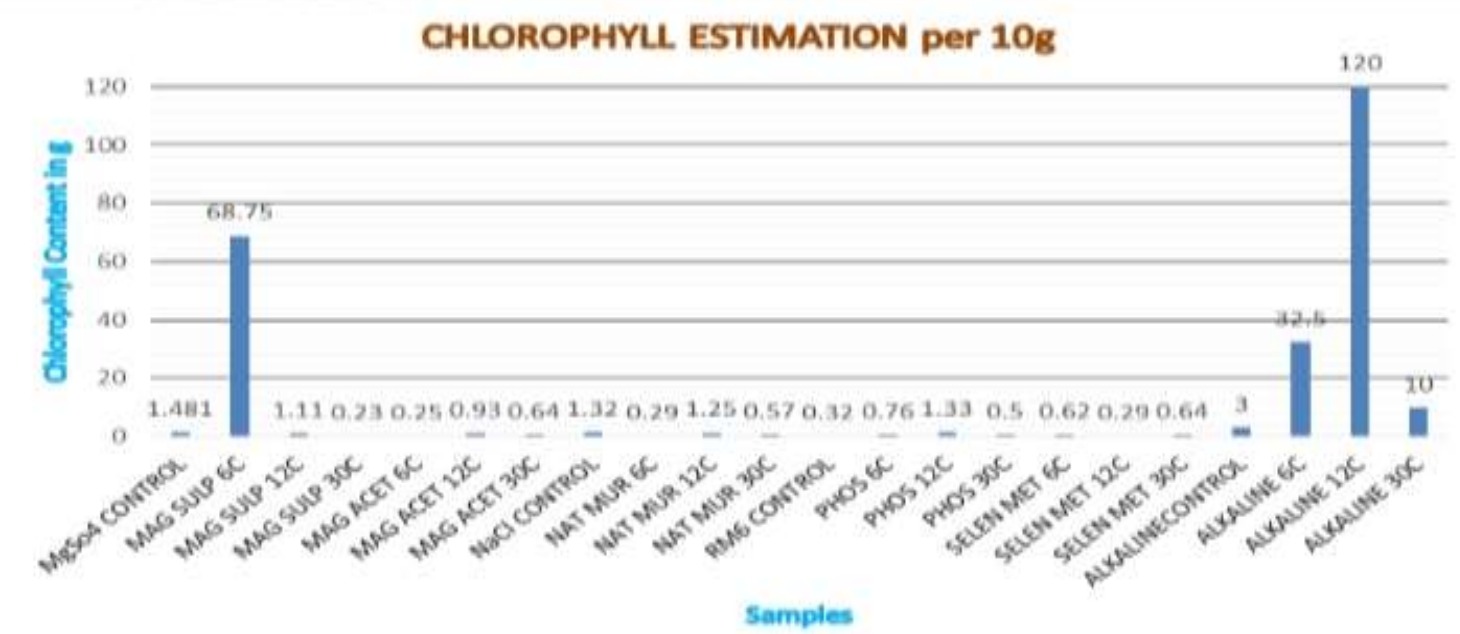

In this graph, the TOTAL CHLOROPHYLL values of each sample were analyzed. Hence the maximum pigmentation seen in MAG SULP 6 C and ALKALINE 12C . The minimum pigmentation was obtained in MAG SULP $30 C$ and shows the protein content of all the samples.

GRAPH : 4

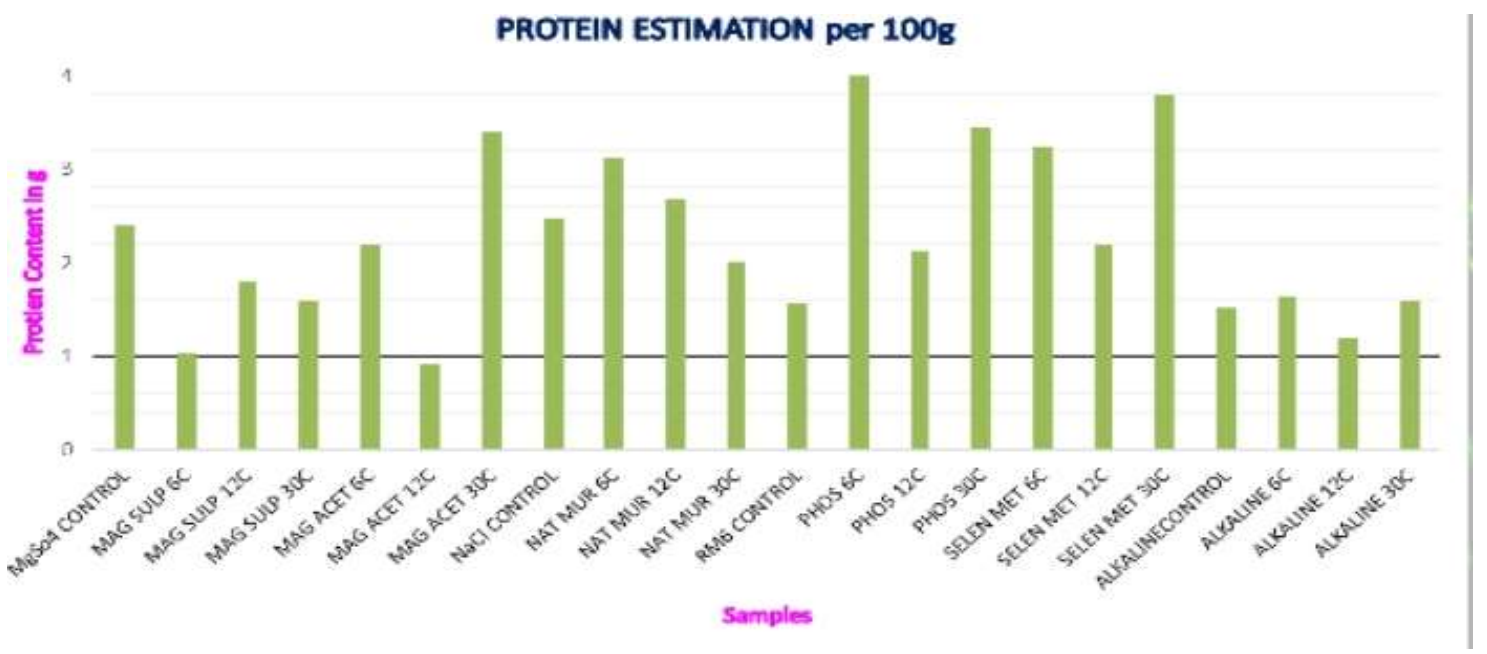

From this graph, the high protein available in PHOS 6C and SELEN MET 30C 
.The low quantity of protein available in sample MAG SULP $6 C$ and MAG ACET $12 \mathrm{C}$.

\section{CONCLUSION}

From these all evidences, here an alternate homoeopathic culture media was formed. The techniques also a cost effective one. This new field paved a way for the upcoming researchers to found a cheaper and healthier Spirulina. These are evidence for the effect of homoeopathic ultra dilutions upon the life of a single celled organism. Thereby linking the field of homoeopathy and cyanobacteriology will give new branch of science, called cyano- homoeopathy.

\section{REFERENCES}

Habib .B Ashsan. M,ParvinMashuda, Huntington.C Tim et al. - A review on culture, production and use of spirulina as a food for humans and feeds for domestic animals and fish FIMA/C 1034

[Internet].Food and Agriculture of Organizations of United Nations :Rome,2008 [Cited on 2018 July 25].Available from : http://www.fao.org.

Piccolo Antonio. Spirulina - a livelihood and a business venture [internet].European union: Mauritius, 2011 [Cited 2018 July 25].Available fromhttp://www.fao.org.

Koru Edis.Earth food Spirulina (Arthrospira) production and Quality standards [internet].Intech: Turkey, 2012[cited 2018
July

25].Available

fromhttp://www.intechopen .com.

\section{Dr. Cysewki R.Gerald, Moorhead Kelly,}

Capelli Bob. Spirulina Nature's Super food [internet]. Cyanotech corporation: Hawaii, 2011 [Cited 2018 July 25].Available from http://www.terapiaclark.es.com.

Gammer Natan.Grow Organic Spirulina [internet].[Cited on 2018 July 26].Available fromhttp://www.groworganic-spirulina.com.

Corner .E.D.S.Phosphorus in marine zooplanktons Water research Volume 7,Issue 1-2 pages 77- 91(Phosphorus in primary aquatic plants).[internet].Elsevier Ltd:1973, [Cited on 2018 July 26]. Availablefrom:http://www.sciencedirect. com.

Chapter -7 Microbial growth Binary fission steps in binary fission generation time, [internet]. [Cited on 2018 July 26].Available from: http://www.yumpu.com.

Li Zhi Yong, Guo Si Yuan, Li Lin. Bio Effects of Selenite on the growth of spirulinaplatensis and its biotransformation.[Internet].2003 January 19 [Cited on 2018 July 25]. Available from :http:// www.sciencedirect.com.

Liu C, et al. Growth and antioxidant production of spirulina in different $\mathrm{NaCl}$ concentrations. [Internet].2016[Cited on 2018 July 27].http:// www.ncbi.nlm.nih.gov. 